\title{
OS DIREITOS HUMANOS A PARTIR DE HANNAH ARENDT
}

André Portugal

HUMAN RIGHTS SINCE HANNAH ARENDT 


\title{
OS DIREITOS HUMANOS A PARTIR DE HANNAH ARENDT
}

\author{
HUMAN RIGHTS SINCE HANNAH ARENDT \\ André Portugal
Advogado \\ Mestre em Direito Constitucional pela Universidade de Coimbra. \\ Portugal \\ andre@kleinportugal.com.br
}

\section{RESUMO}

Este trabalho tem por objetivo analisar a problemática dos direitos humanos a partir da obra de Hannah Arendt. Como veremos, de uma análise do todo do trabalho da filósofa, sobretudo da sua definição de condição humana e de sua interpretação dos regimes totalitários do último século, pode-se encontrar fundamentos e um modus operandi para a garantia de muitos desses direitos.

Palavras-chave: Direitos humanos. Hannah Arendt. Condição humana. Regimes totalitários.

\begin{abstract}
This article has as objective to analyse the human rights problem since Hannah Arendt's work. As we will see, from an analysis of her hole work, specially her definition of human condition and her interpretation of the last century's totalitarian regimes, is possible to find find principles and a modus operandi for this rights guarantee.
\end{abstract}

Keywords: Human rights. Hannah Arendt. Human condition. Totalitarian regimes.

Data de submissão: 21/03/2017

Data de aceitação: 13/06/2017 


\section{SUMÁRIO}

INTRODUÇÃO 1. UMA BREVE DESCRIÇÃO D'A CONDIÇÃO HUMANA 2. OS DOMÍNIOS PÚBLICO E PRIVADO E O CONCEITO DE LIBERDADE 3. AS INÉDITAS EXPERIÊNCIAS TOTALITÁRIAS E A BANALIDADE DO MAL 4. OS DIREITOS HUMANOS A PARTIR DE HANNAH ARENDT. CONSIDERAÇÓES FINAIS.

\section{INTRODUÇÁO}

O objetivo deste trabalho é trazer algumas breves reflexōes, a partir da obra de Hannah Arendt, sobre a fundamentação dos direitos humanos. Como veremos, muitos dos pressupostos arendtianos recaem, justamente, sobre a necessidade do reconhecimento de alguns desses direitos.

O primeiro tópico destina-se a descrever, brevemente, aquela que parece ser a obra de $\mathrm{H}$. Arendt: A Condiçáo Humana. Nela, aparece a distinção entre os três aspectos da vita activa: trabalho, obra e ação. ${ }^{1}$

No segundo, procura-se trazer a importante diferenciação entre os domínios público e privado, também presente em A Condição Humana. Nesse tópico, também há a conceituaçáo de Hannah Arendt para a liberdade, o que julga-se importante para a temática dos direitos humanos.

Por sua vez, o terceiro tópico entra na análise dos totalitarismos do último século. A ruptura que eles representaram, fornece um interessante ponto de partida para se analisar os direitos humanos. Aqui, a descrição de A Condição Humana ganhará ainda mais sentido, porquanto esses movimentos totalitários efetivamente mostraram-se capazes de desconsiderar muitos dos aspectos que condicionam a vida humana na Terra. Vale dizer, é também neste ponto que será tratado o famigerado fenômeno da banalidade do mal.

1 Nas edições anteriores da tradução brasileira, esses aspectos da vita activa eram traduzidos, respectivamente, para labor, trabalho e ação. Na tradução mais atualizada, todavia, labor foi substituído por trabalho e trabalho foi substituído por obra. Optamos, neste trabalho, por utilizar os termos da traduçáo mais atualizada. 
Por fim, analisaremos como os direitos humanos se relacionam com tudo isso. Mais concretamente, o último tópico procura demonstrar que direitos humanos podem ser derivados das premissas e conclusôes do trabalho de Hannah Arendt.

\section{UMA BREVE DESCRIÇÃO D'A CONDIÇÃO HUMANA}

Muito provavelmente, A Condiçáo Humana se trata da grande obra de Hannah Arendt. Nela, aparecem todas as premissas teóricas de que parte a filósofa para analisar tanto as experiências totalitárias (conquanto As Origens do Totalitarismo tenha sido publicada sete anos antes), como os conceitos de violência, política e liberdade, além, é claro, do famigerado caso Eichmann.

Nessa obra, H. Arendt se propóe a projetar luzes na busca da compreensão do mundo em que a vida humana é lançada e do próprio papel desempenhado pelas atividades humanas nesse cenário. Na verdade, A Condiçáo Humana não seria senão as condiçóes de possibilidade do desenvolvimento dessas atividades, nesse horizonte. E, diferentemente de qualquer ideia de natureza ou essência humana, esses condicionamentos "jamais podem explicar o que ou quem somos, pois jamais nos condicionam de modo absoluto”2.

Para tanto, ela lança mão do termo vita activa, o qual designa uma tríade de atividades humanas fundamentais: trabalho, obra e ação, todas fundamentadas em condições mais gerais da existência humana, sobretudo o nascimento e a morte, a natalidade e a mortalidade.

O trabalho vincula-se à satisfação de necessidades humanas vitais. Em outras palavras, trabalha-se para garantir a própria sobrevivência. "A condição humana do trabalho é a própria vida." ${ }^{3}$ Dai é que se cuida de uma atividade que se move sempre "no mesmo círculo prescrito pelo processo biológico do organismo vivo, e o fim de suas 'fadigas e penas' só advém com a morte desse organismo" ${ }^{4}$. A palavra trabalho, portanto, é compreendida enquanto "um substantivo verbal classificado com o gerúndio" ${ }^{5}$, porquanto constitui uma

2 Essa distinção é importante, pois a ideia de natureza humana é sobremodo arraigada nas tradiçôes filosóficas ocidentais. ARENDT, H. A Condiçáo Humana, 2014, p. 13.

3 ARENDT, H. A Condiçáo Humana, 2014, p. 9.

4 ARENDT, H. A Condiçáo Humana, 2014, p. 120.

5 ARENDT, H. A Condiçấo Humana, 2014, p. 103. 
atividade que persistirá enquanto houver vida. Seu produto não tem durabilidade, pois frequentemente é consumido logo após a produção. Esvai-se assim que é concluído. O seu agente é o animal laborans.

Talvez isso fique mais claro com a definição da segunda atividade humana fundamental, a obra. Desta decorre a fabricação da infinita variedade de coisas cuja soma constitui o artifício humano. O homo faber procura estabilidade e solidez. Em termos fenomenológicos, é "essa durabilidade que confere às coisas do mundo sua relativa independência dos homens que as produziram e as utilizam, sua objetividade, que as faz resistir, se opor (stand against) e suportar, pelo menos durante algum tempo, as vorazes necessidades e carências de seus fabricantes e usuários vivos." ${ }^{\prime 6}$ Os produtos da atividade do homo faber, dado o seu caráter durável, acabam por constituir o mundo objetivo a que todos temos acesso, a que todos compartilhamos, por assim dizer. Eles têm a funçáo de estabilizar a vida humana, a partir do que os homens,

\begin{abstract}
a despeito de sua natureza sempre cambiante, podem recobrar sua mesmidade (ameness), isto é, sua identidade, por se relacionarem com a mesma cadeira e a mesma mesa. Em outras palavras, contra a subjetividade dos homens afirma-se a objetividade do mundo feito pelo homem. ${ }^{7}$
\end{abstract}

É a partir desse mundo comum que a convivência humana é possível. Pode-se dizer, tanto por isso, que a "condição humana da obra é a mundanidade."

Como a obra é o produto de um fabricante, o homo faber, pode-se dizer que ela

é executada sob a orientação de um modelo segundo o qual se constrói o objeto. Esse modelo pode ser uma imagem vista pelos olhos da mente ou um esboço, no qual a imagem já passou por um ensaio de materialização por meio da obra. ${ }^{9}$

De todo modo, a orientaçáo do processo de fabricação vem de fora e o precede, tal como as necessidades do processo vital precedem o efetivo processo de trabalho. Além do mais, essa orientação é exclusivamente baseada nas categorias dos meios e do fim, vinculada à

\footnotetext{
6 ARENDT, H. A Condição Humana, 2014, p. 170.

7 ARENDT, H. A Condiçáo Humana, 2014, p. 170.

8 ARENDT, H. A Condiçáo Humana, 2014, p. 9.

9 ARENDT, H. A Condiçáo Humana, 2014, p. 174.
} 
ideia de utilidade ${ }^{10}$. E, dado o seu raciocínio efetivamente finalístico, sua característica é "ter um começo definido e um fim definido e previsível, e essa característica é bastante para distingui-la de todas as outras atividades humanas." ${ }^{11}$ Daí é que, sendo o homo faber o senhor de si mesmo e de seus atos, Hannah Arendt o define como o amo e senhor de toda a natureza. Ele, ao atuar tão somente na companhia da imagem de seu futuro produto, "é livre para produzir e, também a sós, diante da obra de suas mãos, é livre para destruir." 12

A obra diferencia-se não só do trabalho, mas também da ação. Essa última (é a única atividade que) ocorre diretamente entre os homens, sem a mediação das coisas ou da matéria. Corresponde à condição humana da pluralidade, ao fato que não o Homem, mas os homens vivem na Terra e, assim, habitam o mundo. "A pluralidade é a condição da ação humana porque somos todos iguais, isto é, humanos, de um modo tal que ninguém jamais é igual a qualquer outro que viveu, vive ou viverá." ${ }^{13}$ Em outros termos, a pluralidade tem um duplo aspecto, podendo ser caracterizado como igualdade e, paradoxalmente, como distinção.

Se não fossem iguais, os homens não poderiam compreender uns aos outros e os que vieram antes deles, nem fazer planos para o futuro, nem prever as necessidades daqueles que virão depois deles. Se não fossem distintos, sendo cada ser humano distinto de qualquer outro que é, foi ou será, não precisariam do discurso nem da ação para se fazerem compreender. ${ }^{14}$

Trata-se do que H. Arendt chamou de uma "paradoxal pluralidade de seres únicos"15.

A ação relaciona-se diretamente ao discurso e, por conseguinte, à comunicação. Juntos, ambos constituem o meio pelo qual os homens conseguem distinguir a si próprios. Sem o discurso, teríamos robôs que agiriam sem compreender uns aos outros. No agir e no falar, os homens expressam a sua identidade, "na conformação singular do corpo e no som

$10 \quad$ Na medida em que é homo faber, o homem instrumentaliza, e sua instrumentalizaçáo implica a degradação de todas as coisas a meios, a perda do seu valor intrínseco e independente, de tal modo que finalmente não apenas os objetos da fabricação, mas também 'a Terra em geral e todas as forças da natureza' - que claramente vêm a ser sem o auxílio do homem e possuem uma existência independente do mundo humano -, perdem seu 'valor porque não apresentam a reificação resultante da obra. ARENDT, H. A Condição Humana, 2014, p. 194.

11 ARENDT, H. A Condiçáo Humana, 2014, p. 178.

12 ARENDT, H. A Condiçáo Humana, 2014, pp. 178-9.

13 ARENDT, H. A Condiçáo Humana, 2014, p. 10.

14 ARENDT, H. A Condiçáo Humana, 2014, p. 217.

15 ARENDT, H. A Condiçáo Humana, 2014, p. 217. 
singular da voz." ${ }^{16}$ E essa distinçấo carece da pluralidade: somente no meio de outros eu consigo distinguir-me a mim mesmo. Aqui, Hannah Arendt parte de premissas retiradas da fenomenologia, ao vincular a existência à aparência. "Ser e Aparência coincidem", diznos, pois não há ninguém que exista nesse mundo "cujo verdadeiro ser não pressuponha um espectador" ${ }^{17}$. Tudo existe para ser percebido por alguém. Disso decorre que não há nenhum sujeito que não possa - e não vá - ser visto como objeto por um outro sujeito ${ }^{18}$. Metaforicamente, todos os sujeitos aparecem uns aos outros em um palco de apariçấo criado para eles ${ }^{19}$.

"O palco é comum a todos que estáo vivos, mas parece diferente para cada espécie, diferente também para cada espécime individual." ${ }^{20} \mathrm{Na}$ realidade, esse palco é o domínio público no qual nos relacionamos uns com os outros. Tudo isso pressupóe linguagem (porquanto há discurso e comunicação), e, como bem demonstra o segundo Ludwig Wittgenstein, nenhum homem pode jogar sozinho um jogo de linguagem, de modo que a linguagem pressupóe pluralidade, intersubjetividade e continuidade ${ }^{21}$. A açáo, portanto, jamais será possível no isolamento. Essa pluralidade, como a ação, faz parte das condiçóes pioneiras da humanizaçãa ${ }^{22}$.

É verdade que também o animal laborans e o homo faber podem ter um domínio público e aparecer aos outros. Mas, com relação ao primeiro, a despeito de os trabalhadores viverem na companhia uns dos outros, trata-se de um estar junto que é despido de todos os traços característicos da condição humana da pluralidade. Isto porque, sobretudo nas modernas condiçôes de divisão do trabalho, eles acabam por não ser diferenciados entre si: "são todos fundamentalmente iguais por serem o que são como meros organismos vivos."

\footnotetext{
16 ARENDT, H. A Condiçáo Humana, 2014, p. 222.

17 ARENDT, H. A Vida do Espírito, 2011, p. 29.

18 ARENDT, H. A Condiçáo Humana, 2014, p. 30.

19 ARENDT, H. Entre o Passado e o Futuro, 2013, pp. 200-201.

20 ARENDT, H. A Vida do Espírito, 2011, p. 30.

21 WITTGENSTEIN, L. Tratado Lógico-Filosófico * Investigaçóes Filosóficas, 2003, p. 320

22 "Todas as atividades humanas são condicionadas pelo fato de que os homens vivem juntos, mas a ação é a única que não pode sequer ser imaginada fora da sociedade dos homens. A atividade do trabalho não requer a presença de outros, mas um ser que trabalhasse em completa solidão não seria humano, e sim um animal laborans no sentido mais literal da expressão. Um homem, obrando, fabricando e construindo [working and fabricating and building] um mundo habitado somente por ele mesmo, seria ainda um fabricador, embora não um homo faber: teria perdido a sua qualidade especificamente humana e seria, antes, um deus - certamente não o Criador, mas um demiurgo divino como Platão o descreveu em um dos seus mitos." ARENDT, H. A Condiçáo Humana, 2014, p. 28-ss.
} 
Não há igualdade, mas uniformidade, a tal ponto que a cada um compete se sentir não como indivíduo, mas um com os outros, em uma totalidade unificadora: todos são um só, o que é essencialmente antipolítico, por constituir

\begin{abstract}
o exato oposto da convivência que prevalece nas comunidades comerciais ou políticas que - para citar o exemplo de Aristóteles - não consiste em uma associação (koinonia) entre dois médicos, mas de um médico com um agricultor e, de modo geral, de pessoas diferentes e desiguais. ${ }^{23}$
\end{abstract}

Já no que diz respeito ao homo faber, seu palco de aparição é o mercado de trocas, e, inevitavelmente, aqueles que nele se encontram não são vistos como pessoas, mas como fabricantes em cujos produtos nunca exibem a si mesmos, tanto menos suas qualidades e aptidóes. O que está em jogo são, exclusivamente, os produtos. "O impulso que conduz o fabricante à praça pública não é o desejo de encontrar pessoas, mas produtos, e o poder que mantém a coesão e a existência desse mercado não é a potencialidade que surge entre as pessoas quando estas se unem na ação e no discurso, mas um 'poder de troca' (Adam Smith) combinado que cada participante adquiriu em seu isolamento."24 Diferentemente, na ação, os homens aparecem uns aos outros qua homens. A linguagem que permite identifica-los como participantes de um mesmo jogo de linguagem é, também, paradoxalmente capaz de os distingui-los como seres únicos.

H. Arendt vincula o conceito de ação ao de iniciativa. Agir é começar algo novo, inesperado. "É com palavras e atos que nos inserimos no mundo humano, e essa inserção é como um segundo nascimento" ${ }^{25}$. $\mathrm{Na}$ ação, não há qualquer vinculação à necessidade, como ocorre no trabalho, tanto menos previsibilidade quanto aos seus resultados, como se passa na obra. Pelo contrário, o "novo sempre acontece em oposiçẫo à esmagadora possibilidade das leis estatísticas e à sua probabilidade que, para todos os fins práticos e cotidianos, equivale à certeza."

Por isso, "o novo sempre aparece na forma de um milagre." A capacidade de agir equivale à capacidade humana para o inesperado, o infinitamente improvável, o que, repita-se, somente é possível "porque cada homem é único, de sorte que, a cada nascimento [e a cada açâo], vem ao mundo algo singularmente novo."Assim, a ação é a efetivação da condição humana da natalidade - entendida como início e, por conseguinte, como

\footnotetext{
23 ARENDT, H. A Condiçáo Humana, 2014, pp. 265-266.

24 ARENDT, H. A Condição Humana, 2014, pp. 259-260.

25 ARENDT, H. A Condiçáo Humana, 2014, p. 219.
} 
imprevisível -; o discurso, por seu turno, é correspondente à distinção entre todos os homens, representando, justamente por isso, a "efetivação da condição humana da pluralidade, isto é, do viver como um ser distinto e único entre iguais." ${ }^{\text {'26 }}$

Dessa ligação do agir com a possibilidade do inesperado, H. Arendt infere duras críticas ao historicismo, em suas mais variadas feiçóes ${ }^{27}$. Se ao homem for permitido agir - e, segundo ela, a ação, ainda que potencialmente, nunca deixa de existir -, não há como vinculá-lo a mandamentos ou a pressupostos de criadores visíveis ou invisíveis ${ }^{28}$.

Isso porque a "história real, em que nos engajamos enquanto vivemos, não tem criador visível nem invisível porque não é criada. O único alguém que ela revela é o seu herói." ${ }^{29}$ Como se verá adiante, há muito desses pressupostos na detalhada análise arendtiana das duas experiências totalitárias do último século, em As Origens do Totalitarismo.

Além disso, os conceitos de ação e discurso, por conseguinte, de pluralidade, são a base da qual ela parte para a sua conhecida distinção entre poder e violência. $O$ poder depende do assentimento dos destinatários e surge de um agir em comum acordo, ao passo que a violência parte da imposição e, por conseguinte, do uso da força e visa a dominação. $\mathrm{O}$ poder necessita do número; diversamente, "a violência, até certo ponto, pode dispensá-lo, através do recurso aos instrumentos" 30 .

Daí é que, quando Máo-Tsé Tung afirma que "o poder está no cano de uma arma”, esse poder, na verdade, se trata de violência. Ambos são contrários; quando um reina absolutamente, o outro inexiste. Enquanto a violência jamais pode ser legítima, o poder carece dessa legitimidade, oriunda da reuniáo inicial entre pessoas.

Devemos lembrar que a violência não depende do número ou das opinióes, mas dos instrumentos, e os instrumentos da violência, como já tive ocasião de dizer, aumentam e multiplicam, como todos os outros utensílios, a potência humana. Os que se opuserem à violência por meio do simples poder, em breve descobrirão que se confrontam não com homens, mas com artefactos dos homens, artefactos cuja inumanidade e a eficácia destrutiva aumentam na propor-

26 Todas as demais citaçôes diretas deste parágrafo encontram-se em ARENDT, H. A Condição Humana, 2014, pp. 220-221.

27 ARENDT, H. A Condiçáo Humana, 2014, p. 229.

28 ARENDT, H. Sobre a Violência, 2014, pp. 35-6.

29 ARENDT, H. A Condição Humana, 2014, p. 231.

30 ARENDT, H. A Condição Humana, 2014, p. 47. 
ção da distância que separa os adversários. A violência pode sempre destruir o poder; a ponta de uma espingarda pode ser origem das ordens mais eficazes na determinaçáo da obediência mais instantânea e completa. Do que nunca poderá ser origem, é do poder. ${ }^{31}$

O poder, portanto, pressupóe o domínio público: o agir e o falar em conjunto, que representam a efetivação da pluralidade, são a condiçáo de todas as formas de organização política. Por isso mesmo, na medida em que a tirania se baseia no isolamento do tirano em relação aos seus súditos, e dos súditos entre si, através do medo e suspeita generalizados, ela não seria suficiente para gerar poder, razão pela qual "tão logo passa a existir, gera as sementes de sua própria destruição." 32

A política pressupóe ação, portanto, cuja essência é a própria liberdade, a ser exercida, sempre, com os outros ${ }^{33}$. Se a essência da vida humana se encontra justamente na possibilidade de agir, isso deve servir "como um lembrete sempre-presente de que os homens, embora tenham de morrer, não nascem para morrer, mas para começar" ${ }^{\text {" }}$.

\section{OS DOMÍNIOS PÚBLICO E PRIVADO E O CONCEITO DE LIBERDADE}

Se os homens nascem para começar, ou seja, para agir, é necessário que lhes sejam assegurados os meios para tanto. Mais concretamente, isso implica em que aos homens devem ser garantidas determinadas condiçôes de possibilidade para a vita activa, o que envolve, inicialmente, a distinção entre os domínios público e privado e, em segundo lugar, uma reformulação do conceito de liberdade.

O domínio público, como explicitamos linhas acima, consiste justamente no palco em que aparecemos uns aos outros. Pressupóe, tanto por isso, outros que veem o que vemos e ouvem o que ouvimos, o que "garante-nos a realidade do mundo e de nós mesmos" 35 . Esse espaço público é importante, porque garante que as várias perspectivas sejam expostas e

\footnotetext{
31 ARENDT, H. A Condiçáo Humana, 2014, p. 57.

32 ARENDT, H. A Condiçáo Humana, 2014, p. 251.

33 ARENDT, H. A Condiçáo Humana, 2014, p. 290.

34 ARENDT, H. A Condiçáo Humana, 2014, p. 305. Aqui, Hannah Arendt inverte, de certo modo, o postulado do "ser-para-a-morte", de M. Heidegger.

35 ARENDT, H. A Condiçáo Humana, 2014, p. 62.
} 
dialoguem entre si. "É esse o significado da vida pública." ${ }^{36}$ Não obstante, ele somente tolera o que lhe é considerado relevante, digno de ser visto e ouvido, "de sorte que o irrelevante se torna automaticamente um assunto privado." ${ }^{37}$

Daí a necessidade de um domínio privado. H. Arendt relaciona-o à propriedade, mas fala de propriedade enquanto lugar próprio no mundo, náo enquanto riqueza privada. Por outras palavras, a toda pessoa deve ser garantida a possibilidade de se ausentar, ainda que provisoriamente, do domínio público onde se dialoga com os outros. Em seu lugar, entraria um diálogo consigo próprio, a que Hannah Arendt, a partir de Sócrates, chamou pensamento. Eu, apesar de ser um,

$$
\begin{aligned}
& \text { não sou simplesmente um, pois tenho um ser próprio e entro em re- } \\
& \text { lação com esse ser próprio enquanto meu próprio eu. Este si mesmo } \\
& \text { não é uma ilusão, e faz-se ouvir falando-me - e, nesse sentido, em- } \\
& \text { bora seja um, sou dois em um e pode haver harmonia ou desarmonia } \\
& \text { no meu ser próprio. }{ }^{38}
\end{aligned}
$$

Nesse diálogo consigo mesmo é que se encontraria a consciência. O importante nessa relaçáo seria atingir a concordância, porque viver em desacordo com nós mesmos soaria como viver e "estar diariamente em contato com nosso próprio inimigo" ${ }^{39}$. E, como logo se percebe, somente em um espaço privado, próprio, solitário, a pessoa pode refletir sobre seus atos na esfera pública, no palco em que aparece aos outros. Além de se comunicar com os outros, ela precisa dialogar consigo mesma. O domínio público, portanto, carece da companhia de um domínio privado.

Nisso, encontra-se a própria definição arendtiana de pessoa. Segundo H. Arendt, a pessoa difere do simples ser humano, justamente pela condição do pensamento e da consciência, originados desse diálogo consigo próprio. A consciência é que imporia os limites ao que the seria permitido fazer.

São limites que mudam de pessoa para pessoa, de país para país, de século para século, mas o mal ilimitado e extremo só é possível quando estas raízes desenvolvidas pela própria pessoa de cada um e que limitam automaticamente as suas possibilidades se encontram ausentes. ${ }^{40}$

\footnotetext{
36 A importância de ser visto e ouvido por outros provém do fato de que todos veem e ouvem de ângulos diferentes. É esse o significado da vida pública. ARENDT, H. A Condiçáo Humana, 2014, p. 70.

37 ARENDT, H. A Condiçáo Humana, 2014, p. 63.

38 ARENDT, H. Responsabilidade e Juízo, p. 89.

39 ARENDT, H. Responsabilidade e Juízo, p. 89.

40 ARENDT, H. Responsabilidade e Juízo, pp. 90-ss.
} 
O desaparecimento do pensamento, do diálogo consigo próprio, portanto, consistiria na perda do próprio caráter de pessoa. Como veremos, nisso consiste a conclusão da análise de Hannah Arendt sobre os regimes totalitários do último século, nos quais se verificou o que ela chamou de banalidade do mal.

Em suma, deve ser garantido aos indivíduos não somente um domínio efetivamente público, mas também um espaço privado onde o pensamento possa aparecer. Mas os pressupostos da condição humana também lançam luzes sobre outra questáo importante, que também se relacionam diretamente com as distinçóes entre os domínios público e privado. Trata-se da definição de liberdade.

A liberdade é essencialmente política, diz-nos Hannah Arendt, porquanto se relaciona diretamente com a ação. $\mathrm{O}$ conceito não se relaciona com a possibilidade de se fazer o que se deseje, com o livre arbítrio, mas, antes, depende da pluralidade, da companhia de outros. Em outros termos, na medida em que não o homem, mas os homens habitam o mundo, a liberdade náo pode se relacionar com o querer de um indivíduo solitário ou de um grupo específico, mas com o poder, ou, melhor, com a coincidência entre o querer e o poder, este último inevitavelmente dependente do domínio público. "Somente quando o quero e o posso coincidem a liberdade se consuma" ${ }^{41}$. Em outras palavras, liberdade não pode ser sinônimo de vontade, e o poder político não pode ser confundido com $\mathrm{o}$ resultado de um conflito entre vontades individuais, solitárias e não comunicadas entre si. Afinal de contas, "um Estado em que não existe comunicação entre os cidadãos e onde cada homem pensa apenas seus próprios pensamentos é, por definição, uma tirania”“2.

Conforme fala-se, a liberdade não pode ser identificada com a soberania. Os homens jamais serão soberanos, no sentido de não dependerem de outros, e a fundamentação da soberania de um indivíduo ou grupo em especial somente pode se sustentar às custas da soberania de todos os demais. Ou seja, somente se não os reconhecesse como iguais, ou caso se imaginasse como detentor de algum privilégio, é que o indivíduo ou grupo pretensamente soberano poderia lograr algum êxito em seus objetivos. Como logo se nota, isso pode ser bastante perigoso. Além de tudo, mais que reconhecidos como iguais na participação da formação do mundo comum, os indivíduos devem ser reconhecidos como seres únicos e, tanto por isso, também diversos uns dos outros.

Daí a capacidade, inerente a cada um, de contribuir, à sua maneira e de sua perspectiva,

ARENDT, H. Entre o Passado e o Futuro, 2013, p. 210.

42 ARENDT, H. Entre o Passado e o Futuro, 2013, p. 212.
} 
para a construção desse mundo comum, sem ser possível falar de uma vontade geral que, sem se permitir ouvir a todos, a todos represente. Por isso mesmo, pode-se afirmar que essa "soberania dos organismos políticos sempre foi uma ilusão, a qual, além do mais, só pode ser mantida pelos instrumentos de violência, isto é, com meios essencialmente nãopolíticos. Sob condiçóes humanas, que são determinadas pelo fato de que não é o homem, mas são os homens que vivem sobre a terra, liberdade e soberania conservam táo pouca identidade que nem mesmo podem existir simultaneamente.

Onde os homens aspiram a ser soberanos, como indivíduos ou grupos organizados, devem se submeter à opressão e à vontade, seja esta a vontade individual com a qual obrigo a mim mesmo, seja a 'vontade geral' de um grupo organizado. Se os homens desejam ser livres, é precisamente à soberania que devem renunciar." ${ }^{43}$ A liberdade pressupóe a ação, e a ação depende do reconhecimento da "paradoxal pluralidade de seres únicos" que marca a existência humana na Terra.

\title{
3. AS INÉDITAS EXPERIÊNCIAS TOTALITÁRIAS E A BANALIDADE DO MAL
}

\begin{abstract}
“(...) hell is no longer a religious belief or a fantasy, but something as real as houses and stones and trees. Apparently nobody wants to know that contemporary history has created a new kind of human beings - the kind that are put in concentration camps by their foes and in internment camps by their friends. ${ }^{34}$
\end{abstract}

Falou-se, linhas acima, dos equívocos das teorias que procuram reduzir a complexidade do mundo da vida a uma ordem natural ou histórica.

Historicamente, o problema de tudo isso tem consistido em que as falhas e incoerências de cada uma dessas doutrinas têm sido descobertas demasiado tarde, já depois de muitas vítimas terem tido, voluntária ou involuntariamente, a sua vida apagada - por vezes, da própria História. Em outros termos, na medida em que cada obstáculo ao destino inexorável deve ser eliminado, o custo da sustentação de ideologias baseadas nessas

43 ARENDT, H. Entre o Passado e o Futuro, 2013, p. 213.

$44 \quad$ Numa tradução livre: “(...) o inferno não é mais uma crença religiosa ou uma fantasia, mas algo tão real como as casas, as pedras e as árvores. Aparentemente, ninguém quer saber que a história contemporânea criou um novo tipo de seres humanos - o tipo que é colocado em campos de concentração por seus inimigos e em campos de internamento por seus amigos.” ARENDT, H. We Refugees. In Altogether Elsewere, p. 111. Acessível online em <http://web.stanford.edu/dept/DLCL/files/pdf/hannah_arendt_we_refugees.pdf> Acesso em 20 de maio de 2015. 
profecias pode, embora não necessariamente deva, consistir no sacrifício de todos aqueles que a elas se oponham ${ }^{45}$.

Nas experiências totalitárias do século XX, o que se viu foi a tentativa paradoxalmente exitosa de banir a humanidade dos seres humanos. Exceto a mortalidade, os pilares da condição humana de cada um daqueles que foram submetidos a esses regimes foram aniquilados. É nesse sentido que $\mathrm{H}$. Arendt analisa-as enquanto acontecimentos inéditos, incomparáveis a tudo o que já havia sido visto, e sobre os quais, agora vistos como passado, possivelmente o que de mais importante se possa dizer seja: esse "horror indizível"46 não pode se repetir.

Portanto, os totalitarismos, a despeito de diversificadas semelhanças, não se confundem com as ditaduras, tiranias ou autoritarismos ${ }^{47}$. Ao contrário destes dois, cujas principais características se limitam à supressão, em geral violenta, de toda dissidência política ao regime que detém o poder, os governos totalitários almejam o domínio total dos indivíduos que se encontrem sob sua tutela, algo até entấo considerado impossível, sobretudo pelos adeptos do racionalismo, que viam na consciência do indivíduo algo inatingível e, por isso mesmo, uma limitação à atuação de qualquer governo.

Tratava-se, como dizíamos, de algo inédito e alheio a toda a tradição jurídico-política ocidental; era a ruptura com tudo o que, até então, havia sido visto e vivenciado. Daí a perplexidade proporcionada em muitos dos que tentavam descrever analítica ou sociologicamente os fenômenos percebidos.

Em primeiro lugar, pode-se dizer que os movimentos totalitários, antes de atingirem o poder e tornarem-se governo, somente são possíveis onde existam massas, essas constituídas por um sem número de pessoas indiferentes à política, desinteressadas, não filiadas a quaisquer partidos e geralmente insatisfeitas com a sua própria situaçáo social. Do apoio dessas pessoas, vale dizer, sustentou-se o Nacional Socialismo, até a vitória democrática do partido de Hitler ${ }^{48}$.

Sabe-se, principalmente desde Gustave Le Bon e Sigmund Freud ${ }^{49}$, que as massas caracterizamse por uma irracionalidade cuja consequência imediata é o agir passional, no mais das vezes guiado por um líder que usa da demagogia para obter os fins por ele almejado.

\footnotetext{
45 Neste sentido, BERLIN, I. O Poder das Ideias, 2006, p. 39.

46 ARENDT, H. Responsabilidade e Juízo, p. 20.

47 ARENDT, H. As Origens do Totalitarismo, 2008, p. 554.

48 ARENDT, H. As Origens do Totalitarismo, 2008, pp. 410-ss.

49 FREUD, S. Psicologia das Massas e Análise do Eu e Outros Textos, 2011, p. 25.
} 
Ademais, situaçóes de crises econômicas, como se passava na Europa durante o início da década de 30, aliadas a um nacionalismo bastante forte - vide a crença em uma pretensa missão histórica do povo alemão, tão exaltada por Heidegger, em seu discurso de posse na reitoria da Universidade de Freiburg -, transformam-se em uma mola propulsora para a manipulação dessa totalidade amorfa. O processo torna-se muito mais fácil.

A passionalidade e a passividade exigida de seus adeptos e não adeptos, portanto, comprovam a total descrença dos movimentos totalitários quanto ao papel dos indivíduos na condução das suas vidas. A todos, repita-se, era conferida uma única sina: a resignação ao movimento inexorável da Natureza - no caso do nazismo - ou da História - em se tratando do stalinismo -, cujo devir já havia sido corretamente interpretado por seus respectivos profetas.

O objetivo dos projetos totalitários, portanto, consistia em implantar a todos a sua verdade dogmática, independentemente de consentimento. E ambas essas verdades exigiam a transformação completa do homem; inicialmente, este deveria se transformar em um mero objeto do movimento, após o que surgiria um novo homem.

Como os líderes de ambos os regimes haviam corretamente percebido que a "principal característica do homem massificado não é a brutalidade, nem a rudeza, mas o seu isolamento e a sua falta de relaçôes normais" ${ }^{\text {" }}$, o primeiro passo era desfazer todo indivíduo de sua individualidade, aspecto que envolvia, dentre outras particularidades, seus laços pessoais, sua identificação a determinados grupos e suas preferências políticas, morais. O lugar de cada indivíduo neste mundo deveria perder qualquer sentido; o partido ou movimento lhe apareceriam, entâo, como uma luz no meio de um vazio obscuro. Somente assim a submissão ao movimento e o domínio completo de cada um seriam possíveis.

Todavia, antes da consolidaçáo, o que se dava com a chegada ao governo, a resignação total ao projeto exigia a constante propagação da verdade do movimento. Não bastava isolar os indivíduos de seus vínculos até entáo constituídos. Em outras palavras, a massa precisava ser doutrinada, o que inicialmente se dava através de eficientes métodos de propaganda, geralmente operados por distorçôes da realidade.

Os fatos, segundo afirmavam, dependiam exclusivamente de quem os inventasse. Além disso, nada haveria. Em alguma medida, tratava-se de um construtivismo epistemológico exacerbado, em que o papel das profecias, sobretudo em razão futurística das projeçôes

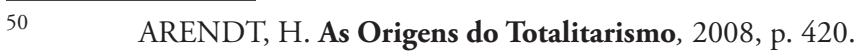


feitas pelo devir histórico ou natural decodificado pelo Führer, no exemplo germânico, adquiria considerável relevância.

Era preciso que o intérprete privilegiado das forças naturais ou históricas se mostrasse infalível. Como, entretanto, os fatos, em si, não significavam nada, mas deveriam ser criados pelos seus intérpretes, nada impedia que todas essas forças acabassem por ser precisamente o que esses seres privilegiados com o dom da visão da Natureza ou da História dissessem que fossem. Para utilizar um exemplo concreto, a "afirmação de que o metropolitano de Moscou é o único do mundo só é falsa enquanto os bolchevistas não

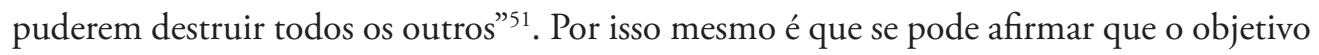
último dos movimentos totalitários é a conquista mundial, pois somente tendo toda a humanidade sob seu controle é que o governante totalitário poderia conferir realidade a todas as suas mentiras, tornando-as verdades ${ }^{52}$. As vítimas ditadas que viessem a ser obrigatoriamente executadas, de acordo com as profecias, transformavam-se em meros álibis retrospectivos, pois nada havia ocorrido fora do que havia sido predito.

Alguém dissera que era quase meio-dia. Shukhov confirmou-o.

- O Sol atingiu já o zénite - anunciou ele. - Se atingiu o zénite disse pensativamente o capitão -, é uma hora, e não meio-dia.

- Quê? - objetou Shukhov. - Os mais velhos sabem perfeitamente que o Sol está no zénite à hora do almoço.

- Os mais velhos, talvez - replicou o capitão. - Mas esses já estão ultrapassados. Recentemente foi publicado um decreto que determina que o Sol apenas está no zénite à uma hora.

- Quem mandou publicar esse decreto?

O Governo soviético. ${ }^{53}$

Mas não era somente isso. $\mathrm{O}$ protocolo, a formalidade, mostrava-se igualmente importante. Daí é que, quando Hitler, por exemplo, dizia prever, em 1939, ao Reichtag alemão, que, caso viesse a eclodir uma nova guerra mundial, por culpa dos financiadores

\footnotetext{
51 ARENDT, H. As Origens do Totalitarismo, 2008, p. 463.

52 "Considerada de um ponto de vista político, a verdade tem um carácter despótico. Ela é por isso odiada pelos tiranos, que temem, com razão, a concorrência de uma força coerciva que não podem monopolizar; e goza de um estatuto relativamente precário aos olhos dos governos que repousam sobre o consentimento e dispensam a coerçáo. Os factos estáo para além do acordo e do consentimento, e toda a discussáo acerca deles - toda a troca de opinióes que se funda sobre uma informação exacta - em nada contribuirá para o seu estabelecimento. Pode-se discutir uma opiniáo importuna, rejeitá-la ou transigir com ela, mas os factos importunos têm a exasperada tenacidade que nada pode abalar a não ser as mentiras puras e simples." ARENDT, H. Verdade e Política,1995, p. 28.
}

53 SOLZHENITSYN, A. I. Um Dia na Vida de Ivan Desinovich, 2003, p. 60. 
judeus, "o resultado será a aniquilação da raça judaica na Europa" ${ }^{4}$, o conteúdo de sua fala, por si só, era considerado insuficiente para a sustentação do mundo fictício em que viviam os subordinados ao regime. Era preciso mais. Aí é que entrava a função simbólica exercida pelos rituais em praça pública, celebrados tanto pelo nazismo, como pelo stalinismo. No primeiro, via-se, nos eventos realizados em Nüremberg, o culto à bandeira de sangue, colocada, sempre, ao centro de tudo; no centro dos rituais soviéticos, por sua vez, era colocado o corpo mumificado de Lenin ${ }^{55}$. Em ambos, o mais marcante era o forte elemento da idolatria, sempre presente nos manuais de doutrinação de massas amorfas. Ficam, assim, sobremodo evidentes os lugares de onde George Orwell tirou sua inspiração para a descrição do mundo distópico de 1984.

Hannah Arendt deixa bastante em evidência que, a despeito de a realidade constantemente desmascarar as pretensas verdades transmitidas pelos líderes de cada movimento, a engenhosidade de cada sistema tornava-o imune a todas essas consequências. O que importava não era a verossimilhança de suas alegaçóes - ainda que eles se esforçassem para que todas elas se tornassem verossimilhantes, vide o exemplo do metropolitano de Moscou -, mas a coerência de tudo o que era difundido. A ficção, pois, deveria ser coerente e organizada, de modo a efetivamente criar um mundo à parte, em competiçấo com o mundo real, "cuja principal desvantagem é não ser lógico, coerente e organizado"s6.

No poder, o movimento se transforma. A propaganda, gradualmente, converte-se em terror, de acordo com a aquisiçáo da perfeição totalitária. O objetivo do governo é manter uma contínua instabilidade, uma revoluçáo permanente; daí é que o Direito, de sua função de estabilização de expectativas, para ficar nos termos de Niklas Luhmann ${ }^{57}$, passa a um mero reprodutor das leis do movimento ${ }^{58}$.

Por isso é que, aos olhos da razoabilidade, tais regimes são de todo incompreensíveis.

Ainda com relaçáo ao modus operandi dos totalitarismos, sobreleva mencionar a importância da definição de inimigos objetivos, sobretudo porque o êxito da profecia assim o exigira. Para tanto, o papel das polícias secretas provaram-se bastante importantes

\footnotetext{
54 ARENDT, H. As Origens do Totalitarismo, 2008, p. 462.

55 ARENDT, H. As Origens do Totalitarismo, 2008, p. 499.

56 ARENDT, H. As Origens do Totalitarismo, 2008, p. 479.

57 LUHMANN, N. Complejidad y Modernidad. pP. 31-ss.

58 LAFER, C. A Reconstruçáo dos Direitos Humanos: um diálogo com o pensamento de Hannah Arendt, 2001, p. 97
} 
- e eficazes.

De início, em períodos que antecedem a tomada do poder, os indivíduos considerados inimigos e, tanto por isso, indesejáveis, são aqueles que, de fato, opóem-se à doutrina, tal como se passa em ditaduras e tiranias vistas em outros tempos. Transcorrida essa fase inicial, com a chegada do partido ou movimento ao poder, passam a ser definidos os inimigos ditos objetivos, cuja culpa incide tâo somente em questôes de caráter objetivo, não relacionado a quaisquer açôes contrárias ao poder dominante. Aqui, o antissemitismo entra em cena, e da determinabilidade, passa-se ao puro arbítrio na definição daqueles que, mesmo sem terem sido acusados de qualquer delito, são declarados indignos de viver. Desse arbítrio ninguém pode, nunca, sentir-se efetivamente protegido ${ }^{59}$.

As diferenças, mais uma vez, para o que se via nos regimes ditatoriais e tirânicos de até então eram gritantes.

O domínio total dos indivíduos somente é atingido quando se alcança a completa homogeneização de suas reaçôes diante de um mesmo fato ou problema. A desumanização deve ser procedida de modo a permitir a sistematização da infinita pluralidade e diferenciação dos seres humanos.

Se a tradição ocidental via tudo isso como impossível, os governos totalitários se encarregaram de demonstrar o contrário. A ruptura colocou em evidência a extensão do poder do ser humano, capaz, inclusive, de desumanizar o seu semelhante.

Esse raciocínio segundo o qual tudo é possível e que vai muito além do tudo é permitido do niilismo, tem seu exemplo mais nítido na experiência dos campos de concentração. Ao fim e ao cabo, comprovava-se que "se pode levar um homem a ser tudo aquilo que dele se pretender" ${ }^{\prime \prime}$.

A prova do aparentemente impossível vinha à tona através de um método de tratamento de indivíduos pelos respectivos governos, colocado em prática, entretanto, antes mesmo do extermínio.

Segundo lembra Hannah Arendt, o primeiro passo para o domínio total consistia na morte da pessoa jurídica do indivíduo, o que deixa bastante claro que o totalitarismo

\footnotetext{
59 ARENDT, H. As Origens do Totalitarismo, 2008, p. 573.

60 SOLZHENITSYN, A. I. Um Dia na Vida de Ivan Desinovich, 2003, p.111.
} 
é precedido de uma série de atos que, em seu tempo, não poderiam fornecer quaisquer previsóes mais sombrias. É o caso, principalmente, das crescentes desnacionalizaçóes efetuadas em desfavor daqueles que futuramente seriam encaminhados aos campos de concentração. Foi, por exemplo, o que Hitler fez na Alemanha, tornando, de modo aparentemente inesperado, apátridas ${ }^{61}$, indesejados, desterrados e proscritos centenas de milhares de seres humanos ${ }^{62}$. Tais pessoas, na medida em que se viam postas fora da lei, sem posição jurídica definida no âmbito da comunidade, perdiam o seu modo particular de existir juridicamente ${ }^{63}$.

A esse respeito, é particularmente interessante a comparação realizada entre o inimigo objetivo já destituído de todos os seus direitos e os criminosos comuns, e as vantagens jurídicas destes com relação àqueles. Enquanto estes, porquanto submetidos aos comandos de uma ordem jurídica determinada, na qual estava prevista a pena a ser aplicada ao seu ato típico, podiam contar com limitaçôes às possibilidades do poder estatal, aqueles, desprovidos de quaisquer direitos e nâo pertencentes a qualquer ordem jurídica, estavam, a bem da verdade, lançados à própria sorte e dependiam puramente do arbítrio da polícia ${ }^{64}$. Portanto, aos apátridas manifestava-se uma situação paradoxal: somente o cometimento de crimes os alçaria à condição de sujeito de direitos.

O último passo, já num estágio mais avançado do totalitarismo, consistia na absoluta eliminaçáo de qualquer individualidade das pessoas enviadas aos campos de concentraçáo, o que se deva já quando de sua chegada a tais lugares: a vestimenta, os cortes de cabelo e o tratamento humilhante.

Os campos de concentraçáo, portanto, eram o ambiente em que o domínio total tornavase possível. As ambiçóes totalitárias atingiam a sua plenitude, na medida em que toda a espontaneidade humana era substituída pela homogeneização. Uma vez aniquilada a individualidade, "nada resta senão horríveis marionetes com rosto de homem, todos com o mesmo comportamento do cão de Pavlov, todas reagindo com perfeita previsibilidade mesmo quando marcham para a morte" ${ }^{15}$.

$61 \quad$ ARENDT, H. We Refugees. In Altogether Elsewere, 2015, p. 110.

62 ARENDT, H. As Origens do Totalitarismo, 2008, p. 592.

63 LAFER, C. A Reconstruçáo dos Direitos Humanos: um diálogo com o pensamento de Hannah Arendt, 2001, p. 109.

64 ARENDT, H. As Origens do Totalitarismo, 2008, pp. 573-574.

65 ARENDT, H. As Origens do Totalitarismo, 2008, p. 603. 
Numa palavra, o terror total, essência de todo totalitarismo, não se manifestava a favor ou contra os homens; o que se pode dizer é que ele se vinculava exclusivamente ao movimento natural ou histórico. Daí por que a liberdade dos homens, tão cara a Hannah Arendt, é, paradoxalmente, tida como obstáculo a esse táo almejado e predito progresso. Ela, a liberdade, representa o fato de os homens nascerem, serem jogados a um mundo já constituído, mas continuada e conjuntamente construído, que persistirá após a existência dos seres humanos de cada geração. Cada nascimento, assim, é um novo começo e, em determinado sentido, o início de um mundo novo. Por outras palavras, há liberdade no começar, ainda que haja uma evidente vinculação de qualquer ação a condiçóes materiais e, até mesmo, tradicionais.

Tudo isso, porém, precisa ser negado pelo totalitarismo, sobretudo porque, sob sua jurisdição, não pode haver liberdade. Tudo deve servir ao movimento. Numa ruptura consistente no hiato entre o passado e o futuro ${ }^{66}$, na medida em que aquele não mais serve de parâmetro para este, a pluralidade de pessoas sucumbe e estas se transformam em um objeto da unidade da Natureza ou da História. Se é possível falar, aqui, em ação, o termo somente pode se referir às práticas destinadas a apressar as profecias. Ou, dito de modo mais prático, quer isso tudo dizer que "o terror executa sem mais delongas as sentenças de morte que a Natureza pronunciou contra aquelas raças ou aqueles indivíduos que são 'indignos de viver' ou que a História decretou contra as 'classes agonizantes' sem esperar pelos processos mais lentos e menos eficazes da própria História ou Natureza” ${ }^{97}$.

O que importa trazer à tona é que tudo que o totalitarismo pretende negar se refere, de modo inexorável, à condição humana, no sentido arendtiano do termo. O totalitarismo literalmente procura - e consegue - desumanizar os seres humanos, mesmo aqueles que compactuam com as diretrizes dos regimes. Isso ficou bastante evidente na análise de $\mathrm{H}$. Arendt sobre o famigerado caso Eichmann.

Como se sabe, AdolfEichmann havia ocupado o posto de tenente-coronel da SS, durante o regime nazista, e a ele eram atribuídas tarefas referentes ao transporte de pessoas, especialmente judeus, aos campos de concentraçáo. Com a derrocada do nazismo, ele se mudou, clandestinamente, para a Argentina, onde, alguns anos depois, foi capturado por uma equipe dos serviços secretos de Israel e posteriormente levado a Jerusalém, onde veio a ser julgado por seus atos durante o regime. Sem adentrar nas manifestas irregularidades do julgamento, precisamente levantadas

66 LAFER, C. A Reconstruçáo dos Direitos Humanos: um diálogo com o pensamento de Hannah Arendt, 2001, p. 75.

67 ARENDT, H. As Origens do Totalitarismo, 2008, pp. 617-618. 
pela própria Hannah Arendt, o que nos interessa é a conclusão de seu trabalho, como jornalista contratada pelo The New Yorker, sobre a postura de Eichmann enquanto partícipe daquele regime totalitário. Ali foi que ela lançou mão do termo banalidade do mal.

Se o principal objetivo dos totalitarismos pode ser resumido à dominação total dos indivíduos, pela via do terror, a sua concretizaçáo somente vem a efeito na medida em que, como falamos, a ação e a liberdade são expurgadas. Mas não é só isso. Dentre os inimigos mais, por assim dizer, abstratos do totalitarismo também se encontra o pensamento, aquele diálogo do indivíduo, que não é simplesmente um, consigo mesmo, já mencionado neste trabalho. Em situaçóes de normalidade, além de prestar contas de seus atos aos homens com os quais compartilha um mundo comum, ele deve explicaçôes a si mesmo, e essa prestação de contas é a que lhe é mais dura, pois, desde que tenha guardados na memória aqueles atos, deles jamais se livrará, a menos que seja perdoado.

Daí é que, diz-nos H. Arendt, cometer uma injustiça seria, ao indivíduo, pior do que sofrê-la ${ }^{68}$. E também por isso é que ela acentua que os "maiores malfeitores são os que não recordam, porque nunca pensaram no que fazem, e porque, não recordando, nada há que os possa fazer voltar atrás." ${ }^{\prime 9}$ Afinal de contas, pensar e lembrar do passado é, sempre, algo profundo, que aos seres humanos "deita raízes e assim os estabiliza, de maneira a impedilos de serem arrastados ao sabor de tudo o que possa acontecer" ${ }^{\text {" }}$. Tomar os exemplos do passado como ponto de partida significa impor limites aos rumos da situaçáo presente; significa, mais que isso, a reflexão e sua decorrente tomada de posição sobre o que já aconteceu, tấo necessárias para que os atos pretéritos que, hoje, são julgados negativamente não venham a se repetir. Como é evidente, o pensamento pressupóe a solidão, o retirarse do domínio público. É precisamente no domínio privado, na intimidade, que ele aparece. Mas no totalitarismo também esse domínio é aniquilado, e a solidão se convola em desolação. Disso tudo resulta a paradoxal destruição da própria condição humana dos seres humanos, acima mencionada.

Os regimes totalitários, na medida em que constituíam verdadeiras burocracias, caracterizaram-se por serem o governo de ninguém e de ninguéns. Esses inúmeros ninguéns formavam as engrenagens dessa imensa máquina burocrática. Ao analisar o julgamento de Eichmann, $\mathrm{H}$. Arendt viu que não se tratava de um monstro sádico e perverso, como o definia a opinião mais difundida e como o esperavam os próprios juízes

\footnotetext{
68 ARENDT, H. Responsabilidade e Juízo, p. 87.

69 ARENDT, H. Responsabilidade e Juízo, p. 85.

70 ARENDT, H. Responsabilidade e Juízo, p. 85.
} 
do processo. "O problema, no caso de Eichmann, era que havia muitos como ele, e que estes muitos não eram nem perversos nem sádicos, pois eram, e ainda são, terrivelmente normais, assustadoramente normais."

Evidentemente, todavia, isso não deveria nos tranquilizar, pois,

do ponto de vista das nossas instituiçóes e dos nossos valores morais, esta normalidade é muito mais aterradora do que todas as atrocidades juntas, pois ela implica (como foi dito inúmeras vezes em $\mathrm{Nu}-$ remberga pelos réus e pelos seus advogados) que este novo tipo de criminoso, sendo, na realidade, um hostis humani generis, comete os seus crimes em circunstâncias tais que lhe tornam impossível saber ou sentir que está a agir erradamente. ${ }^{71}$

O maior dos males, diz-nos, é justamente o mal cometido por ninguéns, "por seres humanos que se recusam a ser pessoas"72, que recusam-se a pensar por si próprios o que estão a fazer e, de igual modo, a pensar, retrospectivamente, aquilo que fizeram, "quer dizer, a voltar atrás e a recordar os seus actos"73. Cuidava-se de sistemas exclusivamente pautados pela violência e que, dada a desumanização por eles provocada, acabavam por generalizar a maldade praticada por homens banais.

O interessante da análise de $\mathrm{H}$. Arendt é que ela não isenta os indivíduos que participaram do mal dos regimes totalitários, ainda que sem pensar o que estavam fazendo. Com efeito, ela rejeita qualquer ideia de culpa coletiva, pois isso implicaria em branquear a culpa, individualizável, daqueles que efetivamente contribuíram para que tudo aquilo ocorresse. Afinal de contas, se todos são culpados, ninguém o e $e^{74}$. Assim é que o fato de serem tão somente engrenagens de um aparato burocrático não os isentaria de suas próprias responsabilidades. Não obstante se tratasse de um regime no qual as condiçóes de possibilidade do pensamento eram bastante reduzidas, porquanto os seres humanos eram basicamente despidos de sua individualidade, a situação referente àqueles que participavam do regime e que, desse modo, praticavam os mais variados atos de cujas consequências tinham consciência, era diferente. Além do mais, em se tratando da aferição da responsabilidade jurídica, não poderíamos, diz-nos Hannah Arendt, nos basear em qualquer determinismo, ainda que ele seja gerado pela burocracia ${ }^{75}$. O horror indizível

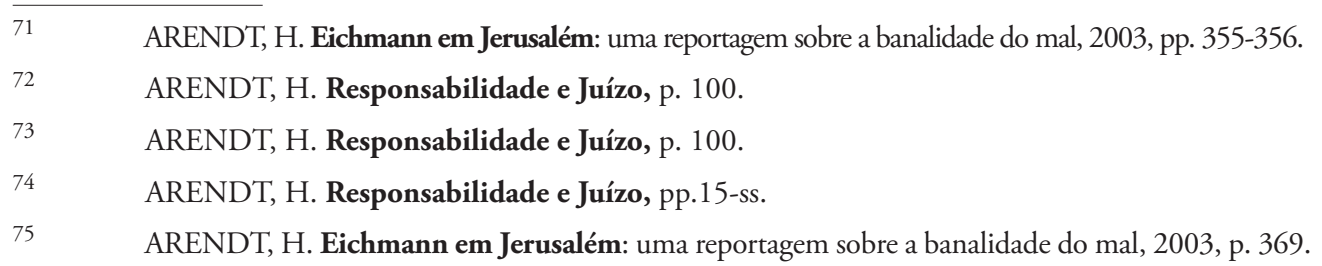


daqueles atos ("matarás - não o teu inimigo, mas gente inocente e que não é sequer potencialmente perigosa; matarás não por necessidade, mas, pelo contrário, ignorando todas as consideraçôes militares ou utilitárias que o desaconselham"76) deveria, por si só, lhes fazer refletir sobre o que estavam fazendo, ou, posteriormente, sobre o que haviam feito. Com efeito, é sempre muito difícil sustentar alguma objetividade em termos de moral, e talvez o máximo que possamos atingir seja alguma objetividade em se tratando de juízos negativos, como fazem, por exemplo, Gustav Radbruch ${ }^{77}$ e Arthur Kaufmann ${ }^{78}$. A justiça, por exemplo, seria bastante difícil de ser definida, mas o mesmo não se passaria com a extrema injustiça, que seria manifesta. É claro que os critérios para a definição da injustiça manifesta não são tão simples de serem identificados. De todo modo, seria por isso que os soldados a quem competia atirar em pessoas inocentes viam-se inevitavelmente confrontados com um imperativo moral segundo o qual eles deveriam desobedecer suas respectivas ordens. Tratava-se, afinal, de uma experiência de ruptura cujos aspectos jamais poderiam deixar de ser percebidos. Em nenhum momento, como analisa H. Arendt, isso ocorreu com Eichmann e outros tantos. "Eichmann pura e simplesmente nunca teve consciência do que estava a fazer" ${ }^{\text {"79. }}$. E esse, como falamos, é o pior dos males. Trata-se, afinal, de um mal que não é radical e não tem raízes, o que promove a sua ausência de limites $^{80}$.

\section{OS DIREITOS HUMANOS A PARTIR DE HANNAH ARENDT}

Especificamente quanto à temática dos direitos humanos, o que se pode extrair de toda a vasta obra de Hannah Arendt é o seguinte: há direitos que precisam ser garantidos, sob pena de violação da própria condição humana que, com o perdão da redundância, efetivamente condiciona toda a existência humana na Terra. Em outras palavras, se, nessa estrada cujo destino parece ser uma nova desumanização, quisermos caminhar pela via oposta, não há nada melhor do que possibilitar aos indivíduos o agir, o que pressupóe discurso, e o pensamento. Além de tudo isso, os exemplos de experiências pretéritas fornecem pontos de partida para a delimitação do que queremos ou poderemos vir a

\footnotetext{
$76 \quad$ ARENDT, H. Responsabilidade e Juízo, p.38.

77 RADBRUCH, G. Filosofia do Direito, 1997, p. 417. Ver também ALEXY, R. Conceito e Validade do Direito, 2011, pp. 34-ss.

78 KAUFMANN, A. Filosofia do Direito, 2014, p. 262.

79 ARENDT, H. Eichmann em Jerusalém: uma reportagem sobre a banalidade do mal, 2003, pp. 366-367.

80 ARENDT, H. Eichmann em Jerusalém: uma reportagem sobre a banalidade do mal, 2003, p. 85.
} 
querer para o futuro. Também aqui, podem ser encontrados fundamentos para a garantia de determinados direitos, especialmente em se tratando daqueles que visem evitar que acontecimentos como os totalitarismos e todas as suas facetas e consequências venham a se repetir.

A ação, como falamos, pressupóe a existência de um domínio público onde os homens possam aparecer uns aos outros e, assim, apontar, pela via do discurso, da comunicação ou, melhor, da linguagem, as suas várias perspectivas sobre aquele mundo comum. Nesse domínio público é que surgem os jogos de linguagem, para ficar com a expressão de Wittgenstein. Afinal, vale relembrar, a não ser na companhia de outros, ninguém é capaz de jogar um jogo de linguagem. Assim, em termos de filosofia política, seria contrária à condição humana qualquer forma de governo que retirasse ou limitasse excessivamente a possibilidade de as pessoas usufruírem desse domínio público para transmitir umas às outras suas perspectivas a respeito da construçáo daquele mundo que, inevitavelmente, será habitado por todos. A ninguém deve ser negada a faculdade de agir, pois o inesperado, como é óbvio, frequentemente vem de onde menos se espera. Mais concretamente, se a condição humana pressupõe a possibilidade de todos agirem, ela rechaça qualquer espécie de tirania ou ditadura. Porquanto vê a ação como o único aspecto da vita activa do qual o homem não pode se livrar sem ser desumanizado, e, uma vez que a ação somente se dá no meio de outros e com-os-outros, sendo essencialmente política, pode-se dizer que $\mathrm{H}$. Arendt nega, também, as várias formas de governo, como algumas vertentes do anarquismo, que apostam na completa independência dos indivíduos com relação aos outros e ao próprio mundo. Para tanto, basta relembrar as suas críticas à muito difundida confusão da liberdade com a soberania: esta é impossível, diz-nos, e, onde exista a soberania de um indivíduo ou grupo específico, inevitavelmente a soberania dos demais perecerá.

Dentre as formas de governo até hoje construídas, a que melhor se adequa à condição humana é, sem dúvida, a democracia. Como falamos nas páginas acima, das relações humanas podem, segundo Hannah Arendt, resultar relaçôes de poder ou violência. Se o poder se origina de um agir em comum acordo, e se, onde há política, deve haver poder, as decisóes políticas devem se pautar, logicamente, pelo consentimento. A democracia parece ser a única forma de governo capaz de promover esse comum acordo. É claro que também ela, sobretudo suas formas clássicas, precisa de reparos, sob pena de não permitir, ao menos não suficientemente, a ação. Daí é que muitas das recentes ideias de democracia deliberativa, caracterizadas por uma aposta bastante alta no papel da sociedade civil, começam a ganhar tanto sentido ${ }^{81}$. Evidentemente, não é o propósito deste trabalho tratar

81 Cf. HABERMAS, J. Facticidad y Validez. pp. 214-ss. 
dessas questôes. O que nos interessa, aqui, é que, porquanto da obra de $\mathrm{H}$. Arendt se depreende a necessidade de uma esfera pública intensa, cuja existência não parece ser possível senão em uma democracia, vários direitos mais concretos passam a ser igualmente imprescindíveis. De modo não exaustivo, é possível mencionar as liberdades de expressão, associação, manifestação, informação ${ }^{82}$ e imprensa, as quais devem ser exercidas em um espaço público que permita que essas associaçóes e grupos livres intervenham, de algum modo, no processo de formação da opinião pública.

Mas não é só isso. Há aspectos que, como diz H. Arendt, não interessam ao domínio público, aos quais somente lhes resta permanecer em domínio privado. Mais especificamente, se a ação necessita de um palco onde possamos aparecer uns aos outros, o mesmo não se passa com o pensamento. Somente no domínio privado, quando nos limitamos à companhia de nós mesmos, é que podemos dar início essa atividade que náo seria senão o diálogo do eu consigo mesmo. E os contornos e detalhes desse diálogo devem ser invioláveis. Por essa razão, aos indivíduos deve ser garantido um lugar próprio no mundo, o que pode ser representado pela propriedade. Daí também é que se retira a importância de todos os direitos fundamentais ligados a esse domínio privado, tais como o direito à intimidade, as liberdades religiosa e de consciência, de movimento, os segredos postal e telefônico, a inviolabilidade domiciliar e a proteçâo do âmbito familiar ${ }^{83}$.

Além de tudo isso, conforme mencionamos, também os exemplos pretéritos podem nos fornecer ensinamentos relevantes em se tratando de direitos humanos. A própria lembrança do passado (ou seja, dos exemplos pretéritos), aliás, pano de fundo para toda reflexão retrospectiva, pode ser alçada ao status de objeto de um direito fundamental: o direito à memória. A inexistência desse direito em muitos ordenamentos parece ser tão somente o reflexo de uma falta de disposiçấo ao aprendizado com o passado. Afinal, vale lembrar, os "maiores malfeitores são os que não recordam, porque nunca pensaram no que fazem, e porque, não recordando, nada há que os possa fazer voltar atrás" ${ }^{\$ 4}$.

Se devemos aprender com o nosso passado, é importante permitirmos que o passado fale e, assim, demonstre sua identidade. E o passado nos fala que uma medida bastante

$82 \quad$ O direito à informação, vale dizer, na medida em que muito se relaciona com a transparência na esfera do público, refere-se, principalmente, à vedação de mentiras e distorçóes da realidade pelos poderes públicos, em uma clara contraposição ao que se passava durante os regimes totalitários, consoante já acentuamos neste trabalho.

A esse respeito, ver HABERMAS, J. Facticidad y Validez. pp. 448-449.

84 ARENDT, H. As Origens do Totalitarismo, 2008, p. 85. 
relevante do "grau de infecção totalitária de um governo" é o uso, em maior ou menor grau, do direito soberano de desnacionalização ${ }^{85}$. Isso porque, em uma sociedade mundial de Estados-nação, a nacionalidade é representativa da cidadania, do estatuto político, de cujo caráter contingente passou a derivar toda a ideia de direitos humanos após a quebra do paradigma jusnaturalista. Dessas medidas de desnacionalização, adotadas durante os regimes totalitários, resultou o crescimento exponencial, em toda a Europa, do número de apátridas, pessoas sem Estado, cuja "situação angustiante não resulta do fato de não serem iguais perante a lei, mas sim de não existirem mais leis para eles" ${ }^{\text {"86 }}$, o que os tornava supérfluos. Os apátridas são, na verdade, "inocentes condenados, destituídos de um lugar no mundo - um lugar que torne as suas opiniōes significativas e as suas ações efetivas" ${ }^{\prime 7}$.

Da análise dessa situação - que havia sido a sua própria -, H. Arendt, sob uma notória influência do existencialismo, deixa bastante em evidência que a igualdade, como os demais direitos humanos, não é algo dado, a ser encontrado em algum lugar ou a partir de alguma experiência transcendental. Pelo contrário, ela é inevitavelmente construída, convencionada e elaborada pelo agir em conjunto que dá origem ao poder. Em linhas gerais: os homens não nascem iguais, eles se tornam iguais ${ }^{88}$. Ao fim e ao cabo, tudo isso envolve a existência de instituições políticas que, ao contrário dos totalitarismos, garantam a igualdade.

Daí é que, como acentuamos, a própria ideia de direitos humanos passa a vincular-se à cidadania, pressuposta como um princípio,

pois a privaçấo da cidadania afeta substantivamente a condição humana, uma vez que o ser humano privado de suas qualidades acidentais - o seu estatuto político - vê-se privado de sua substância, vale dizer: tornado pura substância, perde a sua qualidade substancial, que é de ser tratado pelos outros como um semelhante ${ }^{89}$.

E, como uma das principais ferramentas dos totalitarismos para lograr êxito na generalizaçáo da violência consistia na desnaturalizaçáo, parece lógico que a sua possibilidade deve

85 ARENDT, H. As Origens do Totalitarismo, 2008, pp. 570-ss.; LAFER, C. A Reconstruçáo dos Direitos Humanos: um diálogo com o pensamento de Hannah Arendt, 2001, pp. 143-ss.

86 ARENDT, H. As Origens do Totalitarismo, 2008, pp. 573-ss.

87 LAFER, C. A Reconstruçáo dos Direitos Humanos: um diálogo com o pensamento de Hannah Arendt, 2001, p. 148.

88 ARENDT, H. As Origens do Totalitarismo, 2008, pp. 600-ss.

89 LAFER, op. cit., p. 151. 
ser restringida tanto quanto possível. O direito à cidadania, numa palavra, constitui o direito a ter direitos, o primeiro direito humano ${ }^{90}$, cuja efetivaçấo exige que os homens tenham um lugar próprio no mundo que compartilham e constroem ${ }^{91}$ uns com os outros, enquanto semelhantes. Isso não pode ser alcançado sem a cidadania.

\section{CONSIDERAÇÓES FINAIS}

O século XX efetivamente demonstrou ser possível levar um homem a ser aquilo que dele se pretender, para ficar com a épica frase de Aleksandr Solzhenitsyn. Na ruptura proporcionada pelos movimentos totalitários, o homem foi levado à superfluidade. Porquanto sua condição humana foi aniquilada, pode-se dizer que ele foi efetivamente desumanizado.

A obra de Hannah Arendt ofereceu-nos um ponto de partida importante para analisar aqueles regimes e o modo como eles funcionavam em relação aos direitos humanos. Como vimos, estes não são senão uma construção humana, essencialmente política, e que, bem por isso, em muito se relacionam com a ideia de condição humana. Sem a pluralidade e a natalidade, o que pressupõe ação e discurso, não há verdadeiras comunidades políticas. Não há mundo comum e não há direitos humanos. Por isso a aposta na vita activa, principalmente na ação, é tão importante. Ao contrário do historicismo, em suas mais variadas facetas, que aposta na inevitabilidade de um determinado ponto de chegada histórico, H. Arendt coloca todas as suas fichas no homem e em seu poder de fazer vir à tona o inesperado, o imprevisível. Assim, se tudo indica que caminhamos para uma nova desumanização, marcada pela vitória do animal laborans e pela transformação dos homens em meros autômatos, nada impede que, de onde menos se espera, a ação apareça e dê novos rumos a esse trágico destino.

90 LAFER, C. A Reconstruçáo dos Direitos Humanos: um diálogo com o pensamento de Hannah Arendt, 2001, p. 166.

91 Ao falar em construção de um mundo, Hannah Arendt faz menção ao conceito de mundo enquanto artefato humano, fruto da atividade da obra. É claro que ela náo limita o significado do conceito a isso. Pelo contrário, ela admite a existência de um mundo que existia antes da vinda dos próprios seres humanos e que continuará a existir após a sua partida. Ademais, a própria condição humana consiste em condicionamentos impostos, por assim dizer, alheios ao homem e em condicionamentos criados pelo próprio homem. Por isso mesmo, seria equivocado classificar H. Arendt como uma construtivista epistemológica. Sobre os conceitos de mundo, ver POPPER, K. R. Conocimiento Objetivo, 1982; 


\section{REFERÊNCIAS}

ALEXY, R. Conceito e Validade do Direito. Tradução de Gercélia de Oliveira Batista Mendes. São Paulo: Martins Fontes, 2011;

ARENDT, H. A Condiçáo Humana. Tradução de Roberto Raposo. 12 ed. Rio de Janeiro: Forense Universitária, 2014;

ARENDT, H. A Vida do Espírito: Pensar. Tradução de J. S. Duarte. Lisboa: Instituto Piaget, 2011;

ARENDT, H. As Origens do Totalitarismo. Tradução de Roberto Raposo. Lisboa: Dom Quixote, 2008;

ARENDT, H. Eichmann em Jerusalém: uma reportagem sobre a banalidade do mal. Tradução de Ana Corrêa da Silva. Coimbra: Tenacitas, 2003;

ARENDT, H. Entre o Passado e o Futuro. Tradução de Mauro W. Barbosa. 7 ed. São Paulo: Perspectiva, 2013;

ARENDT, H. Responsabilidade e Juízo. Tradução de Miguel Serras Pereira. Lisboa: Dom Quixote;

ARENDT, H. Sobre a Violência. Tradução de Miguel Serras Pereira. Lisboa: Relógio d'Água, 2014;

ARENDT, H. Verdade e Política. Tradução de Manuel Alberto. Lisboa: Relógio d’Água, 1995 ;

ARENDT, H. We Refugees. In Altogether Elsewere: Writers on Exile. Organizado e editado por Marc Robinson. Disponivel em <http://web.stanford.edu/dept/DLCL/files/ pdf/hannah_arendt_we_refugees.pdf> Acessado em 20 de maio de 2015;

BERLIN, I. O Poder das Ideias. Tradução de Miguel Serras Pereira. Lisboa: Relógio d'Água, 2006; 
DOSTOIÉVSKI, F. Os Demônios. Tradução de Paulo Bezerra. 5 ed. São Paulo: Editora 34, 2013;

FREUD, S. Psicologia das Massas e Análise do Eu e Outros Textos. Tradução de Paulo César de Souza. São Paulo: Companhia das Letras, 2011;

HABERMAS, J. Facticidad y Validez. Tradução para o espanhol de Manuel Jiménez Redondo. 6 ed. Madrid: Trotta Editorial;

HEIDEGGER, M. La Autoafirmación de la Universidad Aleman: Discurso del reitorado. Traduçăo para o espanhol de Ramón Rodriguez. Disponível em: <http:// jeasacademia.wordpress.com/2008/12/20/la-autoafirmacion-de-la-universidad-alemanadiscurso-del-rectorado-m-heidegger/>Acessado em 22 de maio de 2015;

HEMINGWAY, E. Por Quem os Sinos Dobram. Tradução de Monteiro Lobato. Lisboa: Editora Livros do Brasil, 2007;

HUXLEY, A. Admirável Mundo Novo. Tradução de Vidal Serrano. Rio de Janeiro: Globo, 2003;

KAUFMANN, A. Filosofia do Direito. Tradução de António Ulisses Cortês. 5 ed. Lisboa: Fundação Calouste Gulbenkian, 2014;

LAFER, C. A Reconstruçáo dos Direitos Humanos: um diálogo com o pensamento de Hannah Arendt. São Paulo: Companhia das Letras, 2001;

LUHMANN, N. Complejidad y Modernidad. Tradução para o espanhol de Josetxo Berian e José María García Blanco. Madrid: Trotta Editorial;

ORWELL, G. 1984. Tradução de Heloisa Jahn e Alexandre Hubner. São Paulo: Companhia das Letras, 2009;

PFERSMANN, O. Positivismo Jurídico e Justiça Constitucional no Século XXI. Tradução de Alexandre Coutinho Pagliarini. São Paulo: Saraiva, 2014;

PLATÃO, A República. Tradução de Maria Helena da Rocha Pereira. 13 ed. Lisboa: Fundação Calouste Gulbenkian, 2012; 
POPPER, K. R. A Sociedade Aberta e seus Inimigos: O fascínio de Platão. Tradução de Milton Amado. São Paulo: Itatiaia, 1987;

POPPER, K. R. Conocimiento Objetivo. Tradução para o espanhol de Carlos Santos Solis. 2 ed. Madrid: Tecnos, 1982;

RADBRUCH, G. Filosofia do Direito. Tradução de L. Cabral de Moncada. 6 ed. Coimbra: Arménio Amado, 1997;

SOLZHENITSYN, A. I. Um Dia na Vida de Ivan Desinovich. Tradução de H. Silva Letra. Lisboa: Bibliotex Editor, 2003;

WITTGENSTEIN, L. Tratado Lógico-Filosófico* Investigaçóes Filosóficas. Tradução de M.S. Loureiro. 3 ed. Lisboa: Fundação Calouste Gulbenkian, 2003. 
